\title{
Transylvanian Saxon Politics, Hungarian State Building and the Case of the
}

\section{Allgemeiner Deutscher Schulverein (1881-2)*}

On 16 April 1882, at a meeting in Hermannstadt, an important predominantly

German-speaking provincial town in the far South-Eastern corner of the Austro-

Hungarian Monarchy, the following resolution was agreed upon by the Transylvanian

Saxon participants:

We defend ourselves against any thoughts concerning our loyalty to the State and deny with indignation any attempt to represent ourselves and the Saxons in Transylvania as enemies of the Hungarian state ... we are citizens of Hungary and want to remain German ...

The meeting was part of a Hungary-wide series of demonstrations both for and against the acceptance of aid from the recently formed Allgemeiner Deutscher Schulverein (ADS) based in Berlin. ${ }^{2}$ One month later, amidst similar demonstrations in the village

Heltau located five miles south-west of Hermannstadt, the sentiments were similar. ${ }^{3}$ After agreeing to accept aid from ADS, one of the prominent speakers, Dr. Ziegler, reiterated that the Transylvanian Saxons were not against the Hungarian state. He continued: 'And, nevertheless, we are enemies of the State; - because - because we are German and want to remain German'. ${ }^{4}$

This article will look at the Transylvanian Saxon dilemma - in essence, the desire

\footnotetext{
*I would like to thank the Europa Institut Budapest for hosting a lengthy research stay.

${ }^{1}$ Die Deutschen in Ungarn und Siebenbürgen und der 'Deutsche Schulverein' (Hermannstadt, 1882), p. 90. Place names are a contentious issue in Central and Eastern Europe scholarship. In this article for readability the place name in the text will generally be the German version, while the other variants will be referenced in the footnotes eg. Hermannstadt/Nagyszeben/Sibiu. Some place names normally not given in German will be in Hungarian or Romanian for the text with variants in the footnotes. For towns and cities with a commonly used English place name, then English will be used.

${ }^{2}$ The name of the organisation varies between Deutsche Schulverein and Allgemeiner Deutscher Schulverein depending on the document.

${ }^{3}$ Heltau/Nagydisznód/Cisnădie.

[Type text]
} 
to remain linguistically and ethnically German while living as loyal citizens of a Magyar dominated Hungary - in light of a specific series of events and from two perspectives. Immediately upon its foundation in 1881, the ADS offered funds to German communities in Hungary for specific German-language educational and cultural purposes, thus prompting a wave of publicity, diplomatic exchanges, comments in parliament and town meetings. ${ }^{5}$ A snapshot of these few months shows the complex and fluid political landscape the Saxons had to negotiate as well as the considerable divisions within the Saxon community - both in political tactics and in local specificities. To delve into Transylvanian Saxon experiences of a rapidly modernizing and nationalizing Hungary requires recognition of their variety and vulnerability. Particularly important during the ADS incident was the potential involvement of a newly formed and powerful Imperial Germany in Transylvanian Saxon and, therefore, Hungarian affairs. German involvement could take a number of forms. This could involve direct aid from private organisations like the ADS, or attempts to influence official German government policy, or a general call to European public opinion. All were tried at varying times by concerned individuals in Germany, though with little success. During the 1870s there was minimal German interest in the Saxons with only a few isolated publications promoting support for the Transylvanian Saxons. By contrast, this trickle became a veritable flood after the foundation of the ADS in 1881.

This article therefore has a dual focus: first, on the Transylvanian Saxon press and, second, on the various pamphlets circulating in Imperial Germany. How did the

\footnotetext{
${ }^{4}$ Die Deutschen in Ungarn und Siebenbürgen und der 'Deutsche Schulverein, p. 135.

${ }^{5}$ It has been referred to as 'the pamphlet scandal of the Deutscher Schulverein'. See I. Senz, Die Nationale Bewegung der ungarländischen Deutschen vor dem Erstern Weltkrieg. Eine Entwicklung im Spannungsfeld zwischen Alldeutschtum und ungarischer Innenpolitik (Munich, 1977), p. 59.
}

[Type text] 
Saxons act and react during the incident? Could they reconcile being members of the German-speaking Saxon community and loyal Hungarian citizens? What were the perceptions towards and interpretation of events as they unfolded? How interested was the Reich German public in the Saxons' plight? What was the relationship between Imperial Germany and the Saxon political leaders? Finally, how were relations with Imperial Germany and the Hungarian government in Budapest affected?

The historiography on late nineteenth century Transylvanian Saxon history has two main strands within which the events of $1881-2$ can be interpreted. Traditionally, the ADS demonstrations have been portrayed as part of the gradual Transylvanian Saxon move towards a stronger German national consciousness. The powerful influence of Friedrich Teutsch, a Transylvanian Lutheran priest and historian, has been an important factor in the construction of this linear narrative. His interpretation, as outlined in his essay 'The Development of Our National Consciousness' (1895) was that:

The Schulverein demonstrations in Hungary declared from thousands to thousands: [the Transylvanian Saxons] are German and want to remain German; loyalties to the Volk and to the state do not stand in opposition to each other. ${ }^{6}$

In the 1920s, Teutsch, when completing the final volume of the monumental history of the Transylvanian Saxons which his father had begun seventy years earlier, described the Schulverein demonstrations as continuing to live in the collective memory. ${ }^{7}$ Another witness to the demonstrations, Edmund Steinacker, a descendant of Zipser Germans (German communities in modern-day Slovakia), placed the Schulverein events in the

\footnotetext{
${ }^{6} \mathrm{~F}$. Teutsch, 'Die Entwicklung unseres nationalen Bewußtseins' in id., ed., Bilder aus der vaterländischen Geschichte (Hermannstadt, 1895), p. 398. A similar view is expressed, in almost the same words, in Friedrich Teutsch's biography of his father. F. Teutsch., Georg Daniel Teutsch. Geschichte seines Lebens (Hermannstadt, 1909), pp. 301-302.

${ }^{7}$ F. Teutsch, Geschichte der Siebenbürger Sachsen für das sächsische Volk, Vol. 4: 1868-1919 Unter dem Dualismus (Hermannstadt, 1926), p. 89.
}

[Type text] 
same general trajectory, emphasising the nationalist movement's vitality after the turn of the century when he was heavily involved. ${ }^{8}$ The corollary to this viewpoint is a portrayal of the Hungarian government as fundamentally intolerant and consumed with constructing a unitary Magyar nation-state. In this respect, Robert Seton-Watson's work in the early twentieth century was particularly influential in its criticism of the Hungarian government's policies. ${ }^{9}$ A number of subsequent works have followed in these footsteps emphasising, to differing degrees, a combination of developing Saxon-German national consciousness and overbearing Hungarian policies. ${ }^{10}$

The second historiographical strand attempts to place Hungarian government policy - and thus also the Transylvanian Saxon dilemma - in the context of the immense social and economic changes associated with a rapidly modernising region. The Hungarian historians Ferenc Glatz and Peter Hanák have argued that the process of assimilation, so vital to Hungarian ambitions, was largely attributable to general factors of bourgeois transformation, demographic changes and economic development, though

\footnotetext{
${ }^{8}$ E. Steinacker, Lebenserinnerungen (Munich, 1937), pp. 110-12 and 136-45. Other works published in the inter-war period and following this general schema are E. Barta and K. Bell, Geschichte der Schutzarbeit am deutschen Volkstum (Dresden, 1930), K. Bell, ed., Siebenbürgen (Das Deutschtum im Ausland) (Dresden, 1930), E. Weisenfeld, Die Geschichte der politischen Publizistik bei den Siebenbürger Sachsen (Limburg an der Lahn, 1938), F. Valjavec, 'Das deutsche Bürgertum und die Anfänge der deutschen Bewegung in Ungarn', Südostdeutsche Forschungen 3 (1938), pp. 376-94 and F. Valjavec, 'Quellen zu den Anfängen der deutschen Bewegung in Ungarn', Südostdeutsche Forschungen 4 (1939), pp. 465-508. For background to much of the work, in particular the institutional history and the continuties before, through and after the Nazi era see Mathias Beer and Gerhard Seewann, eds., Südostforschung im Schatten des Dritten Reiches. Institutionen - Inhalte - Personen (Munich, 2004).

${ }^{9}$ Most prominently in R.W. Seton-Watson, Racial Problems in Hungary (1908). Similarly, from the same generation, Oscar Jászi talks of '[t]he [Hungarian] policy of an exaggerated unification and an artificial Magyarization'. O. Jászi, The Dissolution of the Habsburg Monarchy (Chicago, 1929), p. 308.

${ }^{10}$ G. Schödl, 'Am Rande des Reiches am Rande der Nation: Deutsche im Königreich Ungarn (18671914/18)' in id., ed., Deutsche Geschichte im Osten Europas: Land an der Donau (Berlin, 1995), pp. 350454; O. Folberth, 'Die Auswirkung des “Ausgleichs" von 1867 auf Siebenbürgen' in T. Mayer, ed., Der österreichisch-ungarische Ausgleich von 1867. Seine Grundlagen und Auswirkungen (Munich, 1968), 4870 and G. Weidenfeller, VDA. Verein für das Deutschtum im Ausland. Allgemeiner Deutscher Schulverein (1881-1918). Ein Beitrag zur Geschichte des deutschen Nationalismus und Imperialismus im Kaiserreich (Bern, 1976).
}

[Type text] 
the government policy of Magyarization clearly contributed. ${ }^{11}$ More recently, Joachim Puttkamer has looked specifically at Saxon schooling and the Hungarian state in the context of an overall modernisation process - a suitably capacious term. ${ }^{12}$ In short, the Transylvanian Saxons and their relationship to the Hungarian state are placed within wider processes of modernisation which were unfolding throughout Europe at the time.

Some recent works have been more aware of the divisions and changing tactics of the Saxon politicians, while retaining a general sense of nationalist teleology. ${ }^{13}$ In this article, I have attempted to describe the path of Saxon politics as strewn with turns, alternative routes, open-ended possibilities and wayward individuals. In parliament, for example, the Saxons were sometimes with the government, sometimes in opposition; sometimes in alliance with others, sometimes free; sometimes united, often divided. The Hungarian government, too, at various times relaxed its policy towards the Saxons. For example, in the late 1880s, the Saxons began negotiations with the Hungarian government for an understanding, which eventually led to the Second Saxon Day on 17 June 1890 and entry into the government coalition. ${ }^{14}$ In the late nineteenth century

\footnotetext{
${ }^{11}$ See, for example, F. Glatz, 'Bourgeois Transformation, Assimilation, and Nationalism' in id., ed., Hungarians and their Neighbours in Modern Times, 1867-1950 (New York, 1996), pp. 33-43; P. Hanák, 'Problems of Jewish Assimilation in Austria-Hungary in the Nineteenth and Twentieth Centuries' in P. Thane, G. Crossick and R. Floud, eds., The Power of the Past. Essays for Eric Hobsbawm (Cambridge, 1984), pp. 235-50 and P. Hanák, 'Verbürgerlichung und Assimilation in Ungarn im 19. Jahrhundert' in Péter Hanák, Ungarn in der Donau-Monarchie. Probleme der bürgerlichen Umgestaltung eines Vielvölkerstaates (Vienna, 1984), pp. 281-319.

12 J. Puttkamer, Schulalltag und nationale Integration in Ungarn. Slowaken, Rumänen und Siebenbürger Sachsen in der Auseinandersetzung mit der ungarischen Staatsidee, 1867-1914 (Munich, 2003), pp. 15-30. See also id., 'Kein europäischer Sonderfall. Ungarns Nationalitätenproblem im 19. Jahrhundert und der jüngere Nationalismus' in M. Fata, ed., Das Ungarnbild der deutschen Historiographie (Stuttgart, 2004), pp. 84-98.

${ }^{13}$ C. Göllner, ed., Die Siebenbürger Sachsen in den Jahren 1848-1918 (Cologne and Vienna, 1988), pp. 108-205 and F. Gottas, 'Die Deutschen in Ungarn' in A. Wandruszka and P. Urbanitsch, eds., Die Habsburger Monarchie Vol. 3. Die Völker des Reiches (2 vols., Vienna, 1980), 2, pp. 340-410.

${ }^{14}$ A short overview with some original sources is provided in G. Egry, 'Ein anderer Ausgleich. Einiges zur Vorgeschichte des Sachsentages 1890', Zeitschrift für siebenbürgische Landeskunde 29 (2006) 1, pp. 5161. See also Göllner, Die Siebenbürger Sachsen in den Jahren 1848-1918, pp. 184-97.
}

\section{[Type text]}


modernisation and Magyarization were facts of life for the Saxon community but they did not necessarily have to go hand-in-hand. In a recent book Rogers Brubaker has asserted that '.. the political costs of harsh nationalizing policies outweighed the ethnolinguistic gains. National movements that might have been won over to the Hungarian state turned irreconcilably against it'. ${ }^{15}$ Nationalist state building was not the only path towards modernization. ${ }^{16}$ Yet both implicitly assume a teleology - whether towards a nation-state or a certain view of modern society. Throughout this article, I have attempted to counter this tendency and tried to contextualise the Schulverein events within the various contingencies, complexities and contradictions of Saxon, Transylvanian, Hungarian, Austrian and German politics of the time.

In her book entitled 'The Land Beyond the Forest', published in 1888, Emily

\footnotetext{
${ }^{15}$ R. Brubaker, M. Feischmidt, J. Fox and L. Grancea, Nationalist Politics and Everyday Ethnicity in a Transylvanian Town (Princeton, 2006), p. 43. The development of Transylvanian bourgeois society in general followed ethnic lines. See the discussion in G. Gyáni, 'Middle Class and Bürgertum in Hungary with Special Regard to Transylvania during the Period of Dualism' in H. Löwe, G. Trontsch and S. Troebst, eds., Minderheiten, Regionalbewußtsein und Zentralismus in Ostmitteleuropa (Cologne-WeimarVienna, 2000), pp. 185-94. It is an open question whether this necessarily had to be the case and whether a supra-national Bildungsbürgertum was a possibility. See the interesting comments in B. Szelényi, 'Enlightenment from Below: German-Hungarian Patriots in Eighteenth-Century Hungary', Austrian History Yearbook 34 (2003), pp. 111-43 and Z. Török, 'The Friend of Progress: Learned Societies and the Public Sphere in the Transylvanian Reform Era', Austrian History Yearbook 36 (2005), pp. 94-120. ${ }^{16}$ Pieter Judson has also pleaded for the decoupling of modernization and nationalism. P. Judson, Guardians of the Nation. Activists on the Language Frontiers of Imperial Austria (Cambridge, Mass., 2006), pp. 7-8. Judson's work is part of a wave of recent works on Central and Eastern European nationalism which question the extent of ethnic identification and nationalist politics. In particular the term 'national indifference' has become frequently used. See Judson, Guardians of the Nation, pp. 1-11 and T. Zahra, Kidnapped Souls: National Indifference and the Battle for Children in the Bohemian Lands, 19001948 (Ithaca, 2008), pp. 1-12. In relation to Transylvania there are interesting discussions in Brubaker, Nationalist Politics and Everyday Ethnicity in a Transylvanian Town, pp. 4-13 and 63-7. In a related argument, Puttkamer questions the actual enforcement of the Magyarization, arguing that in everyday life the effects were often not as harsh as represented. J. Puttkamer, 'Nationale Peripherien. Strukturen und Deutungsmuster im ungarischen Schulwesen 1867-1914' in E. Hárs, W. Müller-Funk, U. Reber and C. Ruthner, eds., Zentren, Peripherien und kollektive Identitäten in Österreich-Ungarn (Tübingen and Basel, 2006), pp. 97-110 and Puttkamer, Ungarische Schulpolitik und deutscher Schulalltag, pp. 32-57.
}

\section{[Type text]}


Gerard wrote of the Transylvanian Saxons that:

... it is a marvel how this little handful of Germans, brought into a strange country and surrounded by enemies on all sides, should have maintained their independence and preserved their identity under such a combination of adverse circumstances. ${ }^{17}$

Constituting approximately $10 \%$ of Transylvania's population (Romanians were $55 \%$ and Hungarians $33 \%^{18}$ ) the Transylvanian Saxons had preserved their sense of community through extensive local autonomy and their strong Lutheran faith. Yet there were also considerable divisions within this community - between towns and regions, ideological viewpoints, generations, political tactics and strong personalities. ${ }^{19}$ In the mid to late nineteenth century, Transylvanian Saxon politics was often perched between a general desire for unity and the realities of deep difference and disagreement.

One major issue was traditional Saxon administrative and political autonomy, which, at differing times, had come under threat from both Vienna and Budapest. Saxon autonomy had a long history and had evolved over the centuries since their settlement at the request of the Hungarian King in the $12^{\text {th }}$ century. In general, it consisted of an independent legal system, Royal Free town status for the important towns, administrative autonomy (including the election of their own officials), representation in the Transylvanian Diet and official acceptance of Lutheranism. The symbol of Saxon

${ }^{17}$ E. Gerard, The Land Beyond the Forest. Facts, Figures and Fancies from Transylvania (New York, 1888), p. 10. Another traveller, Charles Boner, also expressed admiration for the continued existence of the Saxon community. C. Boner, Transylvania; its Products and its People (1865), pp. 69-73 and 374-84.

18 These figures are for the historic principality Transylvania and are based on the census figures of 1880, 1900 and 1910 as presented in Z. Szász, ed., History of Transylvania, Vol. 3 (Boulder, 2002), pp. 555 and 560. The definition in the census depended on mother tongue.

${ }^{19}$ For good short introductions and overviews of Transylvanian Saxon history see Szász, History of Transylvania, Vol. 3; H. Roth, Kleine Geschichte Siebenbürgens (Cologne-Weimar-Vienna, 2003); R.J.W. Evans, 'Transylvanian Saxons: A German Diaspora' in R.J.W. Evans, Austria, Hungary, and the Habsburgs. Central Europe c. 1683-1867 (Oxford, 2006), pp. 209-27; K. Gündisch, Siebenbürgen und die Siebenbürger Sachsen (Munich, 1998) and E. Wagner, Geschichte der Siebenbürger Sachsen. Ein Überblick (Thaur bei Innsbruck, 1990).

[Type text] 
autonomy was the Universitas Saxonum, normally traced to Matthias Corvinus's royal grant of 1486. While its jurisdiction and structure changed considerably over time, by the mid-nineteenth century there was an elected Saxon Count, seven elected seats and the area it administered formed a unified legal, administrative and political whole. ${ }^{20}$ In addition, from 1437 the Saxons were one of the privileged estates within the Transylvanian Diet - along with the Hungarian nobles and the Hungarian-speaking Székely border guards - while the Romanian population were unrepresented.

In more recent times Saxon autonomy and privileges were increasingly subject to parallel, competing pressures of centralisation from Vienna and Budapest. Centralisation from Vienna had a long heritage. It had begun with the reassertion of Habsburg rule in the early $18^{\text {th }}$ century, was pursued with vigour but little success by Joseph II in the 1780 s and continued into the nineteenth century - first, in the Metternich years and then, more rigorously, in the neo-absolutist era of the 1850s. In general the privileges and institutions of Saxon autonomy had withstood bureaucratic and religious pressures from the Imperial centre and had often reasserted legitimacy after periodic bouts of standardisation and administrative reform. Despite the dynasty's Catholicism and Vienna's attempts to centralise administration, the Saxons often expressed their loyalty to the Monarch and appealed directly for royal favour and protection.

The drive for political control from Budapest was a more recent phenomenon and stemmed from the desire for a modern, greater Hungarian nation-state, including Transylvania. In medieval times Transylvania had been subservient to the King of Hungary but, during the Turkish occupation in the $16^{\text {th }}$ and $17^{\text {th }}$ centuries, had flourished

\footnotetext{
${ }^{20}$ The seven towns were Hermannstadt, Kronstadt/Braşov/Brassó, Mediasch/Mediaş/Medgyes, Schäßburg/ Sigishoara/ Segesvár, Bistritz/Bristriţa/Beszterce, Mühlbach/Sebeş/ Szászsebes and

[Type text]
} 
as an independent Principality. After the Habsburg conquests of the late $17^{\text {th }}$ century, Transylvania continued to be treated as a separate administrative province within the Habsburg Monarchy, while nominally remaining part of the traditional Kingdom of Hungary. Following the revival of Magyar culture and political dominance in the Hungarian Reform Era (1825 to 1848), the idea of an integrated Hungarian nation-state was increasingly mooted by Hungarian elites. Amidst the tumultuous events of $1848-$ including a Hungarian government in Budapest with control over the national budget, troops and foreign policy - the Transylvanian Diet at Klausenburg voted for Union with Hungary on 29 May $1848 .{ }^{21}$ Ultimately, Transylvania was governed from Budapest for only a short time before civil war broke out between Habsburg loyalist forces (led by the Croats under Josip Jelačić) and the defenders of the Hungarian government. In the conflict, the Saxons and Romanians generally sided with the Habsburgs, while many moderate Magyars, such as Ferenc Deák, István Széchenyi and József Eötvös, could not take the step of opposing their King and retired from active politics. Nevertheless, Lajos Kossuth and his supporters fought on until their capitulation to Russian forces at Világos on 11 August $1849 .^{22}$

From 1849 to 1867 the Habsburg Monarchy underwent a series of transformations as Emperor Francis Joseph and successive governments attempted to achieve social, political and national equilibrium. Initially, Transylvania was governed directly from Vienna which included the removal of Saxon autonomy in 1853. Following military defeat and internal pressure, Emperor Francis Joseph introduced in quick succession the federalist October Diploma of 1860 and the more centralist February Patent of 1861. The

Broos/Orăştice/Szászváros.

${ }^{21}$ Klausenburg/Cluj/Kolozsvár.

[Type text] 
new centralist system was based on a unitary Empire-wide constitution, an Imperial parliament sitting in Vienna and overall Austro-German predominance. As German speakers the Saxons were important potential supporters of the new system and their autonomy was revived by the Imperial government in May 1861. The Saxons even sat with the Romanian representatives in a reconstituted Transylvanian Diet at Hermannstadt from 1863 which, along with passing a host of progressive laws, duly sent delegates to the central parliament in Vienna from 1863 to $1865 .{ }^{23}$ Yet the Magyar political elite led by Ferenc Deák refused to reconcile with the Viennese government, defended the legitimacy of the early 1848 laws (while distancing themselves from the later excesses) and boycotted both the Transylvanian Diet and the Viennese parliament. By 1865, amidst foreign policy setbacks and boycotts from the Czechs and Magyars, the February Patent system was clearly breaking down. Defeat by Prussian forces in 1866 prompted Francis Joseph to decide for reconciliation with Hungary, which eventually resulted in the 1867 Ausgleich, forming the Austro-Hungarian Monarchy. It essentially left domestic affairs to the Hungarian government while the Emperor-King retained control of foreign policy, the armed forces and financial matters. The reconvened Transylvanian Diet, now meeting at Klausenburg with a manufactured Magyar majority, repeated the action of 1848 and voted for Union with Hungary. ${ }^{24}$ Thus, after years of uncertainty, the 1867 dualist system

\footnotetext{
${ }^{22}$ Hellburg/Világos/Şiria.

23 The Hermannstadt Diet which sat from 1863 to 1865 is covered well in S. Retegan, 'Die Siebenbürgischen Landtage 1848 bis 1865 ' in H. Rumpler and P. Urbanitsch, eds., Die Habsburgermonarchie 1848-1918. Vol. 7: Verfassung und Parlamentarismus. Part 2: Die Regionalen Repräsentativkörperschaften (Vienna, 2000), pp. 2326-43. The importance of this Diet for the Romanians, the first time they were accepted in the Transylvanian Diet as equals, is highlighted in K. Hitchins, 'The Rumanians of Transylvania and the Ausgleich, 1865-1869', in L. Holotík, ed., Der österreichischungarische Ausgleich (Bratislava, 1971), pp. 860-96.

24 There is a good collection of documents providing a background to this action and later attempts for Union in Aemtliche Actenstücke, betreffend die Verhandlungen über die Union Siebenbürgens mit dem Königreiche Ungarn, 2 Vols. (Hermannstadt, 1865-66).
}

[Type text] 
gradually took hold and it would be the Hungarian government, with an unbreakable majority in the Budapest parliament, which would decide future policies in Transylvania.

The Saxon politicians were split into two factions over the new Hungarian government. The 'Old Saxons', based in the conservative provincial, bureaucratic capital of Hermannstadt, advocated continued adherence to Saxon local autonomy and opposition to Transylvania's Union with Hungary. There was even talk of a possible parliamentary boycott since there was widespread belief that the dualist system would not last long. ${ }^{25}$ On the other hand, the 'Young Saxons', mostly from the more mixed, vibrant Kronstadt, argued for co-operation with the Hungarian political elite on the basis of a common progressive, liberal programme. ${ }^{26}$ In the towns of Reps and Schäßburg there was also strong support for the 'Young Saxons' ${ }^{27}$ While the main reason for the split was the willingness (or not) to co-operate with the Magyar political elite over the construction of a liberal Hungarian state, other factors also played a role. Traditional rivalry between Hermannstadt and Kronstadt, the different milieus of the towns, generational tension and personal clashes contributed, as well as pragmatic calculations about railway routes to the Orient. $^{28}$

\footnotetext{
${ }^{25}$ Teutsch, Georg Daniel Teutsch, 232. There is a good representation of 'Old Saxon' views in the memorandum sent to the Monarch dated 3 March 1866 which is reproduced as an appendix in Teutsch, Georg Daniel Teutsch, pp. 568-83.

${ }^{26}$ See C. Göllner, 'Erwartungen und Enttäuschungen der Siebenbürger Sachsen (1867-1876)', Forschungen zur Volks- und Landeskunde 30 (1987) 2, pp. 9-36 and Göllner, Die Siebenbürger Sachsen, 128-36.

${ }^{27}$ Teutsch, Georg Daniel Teutsch, p. 228.

${ }^{28}$ For comments on politics and railway lines see the short discussion in W. Bruckner, 'Die politische Entwicklung von 1860-1876' in Hundert Jahre sächsischer Kämpfe. Zehn Vorträge aus der Geschichte der Siebenbürger Sachsen im letzten Jahrhundert (Hermannstadt, 1896), pp. 253-8. By the 1860s the two possible routes were Budapest-Klausenburg-Kronstadt (ie. bypassing Hermannstadt) or Budapest- UnterWintz/Alvinc/Vinţu de Jos- Hermannstadt - Roten Turm Pass/Pasul Turnul Roşu/Vöröstoronyi-Szoros (ie. bypassing Kronstadt). For background see G. Rosegger and J. Jensen, 'Transylvanian Railways and Access to the Lower Danube, 1856-1914', East European Quarterly 29 (1996), pp. 427-48 and M. Tanase, 'Railways, towns and villages in Transylvania (Romania): Impact of the Railways on Urban and Rural Morphology' in R. Roth and M. Polino, eds., The City and Railway in Europe (Burlington, 2003), pp. 4560. Eventually the railway was built running through Kronstadt.
}

[Type text] 
Part of the disunity of the Saxons can be attributed to the contrasting characteristics and traditions of Saxon towns. ${ }^{29}$ For example, the two main Saxon centres - Kronstadt and Hermannstadt - were very different. Kronstadt was a bustling, industrial, trading town where the 'Young Saxons' predominated. Its dynamism and openness could explain the 'Young Saxons' willingness to co-operate with the Hungarian government in the 1860 s and 1870 s, especially while the issue of the main railway route to the Black Sea remained undecided. By contrast, Hermannstadt was an administrative, religious, military and institutional centre with a more conventional and cautious outlook. In the uncertain days of 1865-67, the 'Old Saxons' based in Hermannstadt appealed directly to the Monarch, defended their privileges and asserted Transylvania's separate existence all traditional tactics based on historical legal arguments. The 'Old Saxons', unlike the 'Young Saxons', were reluctant to embrace the new dualist, liberal system and its possibilities. Instead they looked to entrenched authority which, in the context of the mid1860s, meant Emperor Francis Joseph in Vienna.

Over time there were important changes both politically and demographically to the different milieus of Hermannstadt and Kronstadt. In Hermannstadt the Saxon community remained dominant in local institutions, in the economy and in overall numbers. While there was growth in both Romanian and Hungarian residents in the last decades of the nineteenth century, there was never a threat to local German dominance. ${ }^{30}$ Hermannstadt also formed the centre of Romanian activity - being the home to the

\footnotetext{
${ }^{29}$ For some background see H. Roth, ed., Handbuch der Historischen Stätten: Siebenbürgen (Stuttgart, 2003) which provides a general overview of the major towns. id., Hermannstadt. Kleine Geschichte einer Stadt in Siebenbürgen (Cologne - Weimer - Vienna, 2006) and id., Kronstadt in Siebenbürgen. Eine kleine Stadtgeschichte (Cologne - Weimer - Vienna, 2010) provides some good background information.

${ }^{30}$ In 1880 the town numbered 14,327 Germans, 2,065 Hungarians and 2,810 Romanians and in 1910 16,832 Germans, 7,252 Hungarians, 8,824 Romanians.
}

[Type text] 
Metropolitan Bishop and to organisations like the Romanian cultural organization ASTRA - and relations between the German and Romanian population were normally quite good. In politics the Saxons' attitudes towards dualism and the associated Magyar hegemony gradually moved from early opposition to resigned co-operation. In the mid to late 1880s, a grouping called the 'Blacks', which included many 'Old Saxons', despaired at any possible change in the political system and argued for a rapprochement with the present entrenched authority in Budapest, even contemplating formal co-operation with the Hungarian government. This pro-government line was coupled with an increased focus on economic, cultural and organisational activities on a local level. For example, the Saxon leader Karl Wolff resigned from the editorship of the influential Siebenbürgisch-Deutsches Tagesblatt to become a bank director and vocal advocate of Saxon associations. Throughout his long life Wolff worked tirelessly for the Saxon community but his approach changed from a stance of direct confrontation in his youth towards a gradual acceptance of the existing political situation in the mid 1880s. As a young law student in Heidelberg in the late 1860s, Wolff - a native of Schäßburg - wrote a number of prominent newspaper articles opposing Magyar interference in Saxon affairs. He worked at the prestigious Neue Freie Presse both in Vienna and then as its Budapest correspondent before returning to Transylvania to edit the Siebenbürgisch-Deutsches Tagesblatt. In this role and then as a parliamentary representative in Budapest, he quickly became immersed in Saxon and Hermannstadt's politics. Throughout the 1870s and early 1880s in print and in parliament Wolff openly challenged the government's policies. ${ }^{31} \mathrm{By}$

\footnotetext{
${ }^{31}$ See Kroner's introduction in K. Wolff, Schriften und Reden (Michael Kroner, ed.) (Bucharest, 1976), pp. 7-40 which provides a good, short overview of Wolff's life in the centre of the Saxon community. See also R. Ungar, 'Carl Wolff (1849-1929) in Dieter Drotleff, ed., Taten und Gestalten. Bilder aus der Vergangenheit der Rumäniendeutschen, 2 Vols, I (Hermannstadt, 2002), pp. 106-10; C. Göllner, 'Karl
}

[Type text] 
the mid 1880s, however, despairing at the Saxon situation and resigned to Magyar political dominance, he retired from public life and worked behind the scenes for a political compromise which would include official Saxon support for the government in Budapest.

The political attitudes of Kronstadt's Saxon community moved in the opposite direction to Hermannstadt's. In the 1860s Kronstadt was the centre of the 'Young Saxon' movement arguing for co-operation with the Hungarian government in Budapest. By the early 1890s, however, Kronstadt's younger Saxon generation had coalesced into the German nationalist 'Green' movement which preached opposition to the Hungarian government; even countenancing alliances with other minority groups. This change can be attributed to a number of factors. There was considerable concern over the situation of the Saxon people amongst the younger generation of politicians, particularly in light of the 'Blacks' opportunistic rapprochement with the Hungarian government. In addition, the Hungarian government's centralising policies showed no sign of abatement, with or without the co-operation of the Saxons. Finally, Kronstadt's demographic dynamics also played a role. In 1880 Kronstadt had an almost balanced mix of nationalities $(9,599$ German, 9,508 Magyar, 9,079 Romanian), though the Saxons dominated local politics and business. While there was some evidence of informal ghettos - German speakers concentrating in the inner city around the Black Church and Honterus Gymnasium with the Romanians in the upper city and the Hungarians in the suburbs - relations between nationalities were characterised by pragmatism and tolerance. Over the next thirty years, however, Kronstadt's demographics changed considerably. By 1910 the Hungarian-

Wolff's Politisches und Wirtschaftliches Wirken', Forschungen zur Volks- und Landeskunde 16 (1973), pp. 5-38 and F. Sachsenheim, Unvergeßliches aus dem Leben Karl Wolff's (Schäßburg, 1933), written by the

[Type text] 
speaking population had risen substantially to relative prominence (10 841 German, 17

831 Magyar, 11786 Romanian) while the Romanian speakers were also growing at a faster rate than Kronstadt's Saxons. These trends were expected to continue and presented a considerable challenge to Saxon dominance at a local level. ${ }^{32}$

Thus the Saxon experience of late political life in the Habsburg Monarchy - with its elections, parliaments, heightened nationalism, constitutional government, organisational life and state building in a time of immense social and demographic changes - was individualised, localised, extremely varied and changed over time. In the founding years of dualism the 'Young Saxon' movement demonstrated that there was a real chance for an understanding between the dominant Hungarian government and the less intransigent Saxon politicians. Yet over the next decade, in piecemeal fashion, the Saxons lost many aspects of their local autonomy and faced continual pressure from the government's drive for a modern, Magyar-dominated, unitary nation-state. Particularly contested was the 1876 law stripping the Universitas Saxonum of its rights and privileges while Transylvania's administrative districts were also fundamentally redrawn to favour the Magyar-speaking population. ${ }^{33}$ The Saxon community were again divided over

\footnotetext{
husband of Wolff's niece and containing extracts from personal correspondence and family reminisences.

${ }^{32}$ Here Kronstadt presents some parallels to the situation in Bohemia where the migration of Czech speakers to previously German-language towns created much national tension, though there were longstanding traditions of co-existence in Transylvania and the Saxons had no pretence of an overarching central state protecting their interests. See M. Cornwall, 'The Struggle on the Czech-German Language Border, 1880-1940', ante, CIX (1994), 914-51.

${ }^{33}$ For accounts of the process see E. Neugeboren, 'Die Zertrümmerung des Sachsenlandes 1876' in Teutsch, Bilder aus der vaterländischen Geschichte, pp. 361-72, Göllner, Die Siebenbürger Sachsen, pp. 160-9, C. Göllner, 'Die Auflösung der sächsichen Nationsuniversität (1876). Vorgeschichte und Folgen' in W. Kessler, ed., Gruppenautonomie in Siebenbürgen. 500 Jahre siebenbürgisch-sächsiche Nationsuniversität (Cologne and Vienna, 1990), pp. 355-66, F. Gottas, 'Das Ende der Nationsuniversität und deren Ablösung durch die evangelische Kirche im Spiegel der Berichterstattung des SiebenbürgischDeutschen Tageblattes' in Kessler, Gruppenautonomie in Siebenbürgen, pp. 367-88 and F. Gottas, Ungarn im Zeitalter des Hochliberalismus. Studien zur Tisza-Ära (1875-1890) (Vienna, 1976), pp. 191-2. The transcripts of the parliamentary debate were published in Die Zertrümmerung des Siebenbürger Sachsenlandes. Nach den Debaten des ungarischen Landtages am 22, 23, 24 und 27 März 1876 (Munich,
}

[Type text] 
political tactics. Some, such as the respected economist and historian Oscar von Meltzl, insisted that the Saxons had to work with the government in Budapest. ${ }^{34}$ Others, such as Karl Wolff, fought vigorously against the 1876 law.

The situation for the Transylvanian Saxons in the early 1880s therefore reflected the realities of the Monarchy's dualist structure and Saxons' position as a small, vulnerable minority within a greater Hungary. While the Saxons had traditionally been a significant, privileged minority in Transylvania, they were a mere $1 \%$ of greater Hungary's population. Adolf Zay, the parliamentary representative for Mühlbach, when discussing political tactics concerning the 1879 Trefort Education Laws, which required the teaching of the Hungarian language in primary schools, noted in a private letter that if two million Romanians and two million South Slavs could not prevent the law, then 200,000 Saxons would not make any difference. ${ }^{35}$ Practically, in the absence of substantive local autonomy, the Saxons needed allies in the new political world. The 'Young Saxons' (and increasingly in the 1870s some 'Old Saxons' as well) believed in working with the Hungarian government in Budapest. There had been a long history of co-operation with the Hungarian nobles in Transylvania based on respect for Saxon autonomy and common membership in the Diet and many Saxons believed co-operation with the Hungarian government in Budapest was the best course. Others, however,

1876). For a good short introduction to the institution of the Universitas see W. Kessler, 'Universitas Saxonum - Personenverband - Gruppenautonomie - Volksgruppe' in Kessler, Gruppenautonomie in Siebenbürgen, pp. 3-27. The Universitas's sole purpose after the 1876 law was to administer its collective property, which included school funding.

${ }^{34}$ See, for example, O. Meltzl, Die Stellung der Siebenbürgen Sachsen in Ungarn (Hermannstadt, 1878). Franz Gebbel, a highly regarded journalist and the first editor of the Siebenbürgen Deutsches Wochenblatt, also argued for co-operation with the Hungarian government, even during the events of 1876, as did Guido von Baußnern. Baußnern, Deutschland und Österreich-Ungarn, 73-82.

${ }^{35}$ Letter dated 26 February 1879 from Adolf Zay to Georg Daniel Teutsch. M. Vlaicu, ed., Briefe an Georg Daniel Teutsch (Bucharest, 1994), p. 246. These sentiments were echoed by Karl Wolff in 1895when there

[Type text] 
looked elsewhere for possible political allies. For a short period in the 1860s the Saxons had worked in harness with centralist, liberal Austro-German circles and Transylvanian Romanian representatives, yet after the dualist settlement of 1867 the Austrian government and politicians were no longer prepared to intervene in the Hungarian half of the Monarchy and few Saxons contemplated an alliance with the Romanians alone. The newly formed Imperial Germany was another matter. The Saxons had long standing educational links with Protestant Germany and there had been a number of pamphlets in Germany during the 1870 s detailing the Magyarizing policies and the Saxon plight. $^{36}$ Moreover, Germany and Austria-Hungary had formed the Dual Alliance in 1879 which brought an official, diplomatic status to Germany's relations with the Habsburg Monarchy. Many Saxon leaders welcomed moral and financial support from Germany without wanting to upset the government in Budapest. Within this complex political constellation, the Saxons attempted to balance a defence of their identity (the characteristic which impressed Emily Gerard so much) with a general recognition of Hungarian political dominance. The myriad of Saxon viewpoints pointed to the difficulty of this balancing act.

$* * *$

On 8 and 9 June 1881, in anticipation of imminent parliamentary elections, the

was a discussion about founding a Saxon national party following the model of the Romanians. See Göllner, Die Siebenbürger Sachsen in den Jahren 1848-1918, pp. 196-7.

${ }^{36}$ For example, [Anon.], 'Ungarn und die Sachsen in Siebenbürgen (Aus Hermannstadt)' in H. Treitschke and W. Wehrenpfennig, eds., Preussische Jahrbücher 29 (1872), pp. 629-39; F. Löher, Die Magyaren und andere Ungarn (Leipzig, 1874) and W. Wattenbach, Die Siebenbürger Sachsen. Ein Vortrag (Munich, 1882 orig. 1870).

[Type text] 
Kronstädter Programme for a Saxon People's Party (Kronstädter Programme der Sächsischen Volkspartei) was drawn up. Its argument for strict opposition to the government only reflected one current in Transylvanian Saxon politics yet its formation and growing influence reflected the change in tone after the 1876 Law severely curtailed the Universitas Saxonum's rights and privileges. ${ }^{37}$ The Church and the various Saxon cultural associations became increasingly important as administrative autonomy was reduced and the official Universitas lost its powers.

With the onset of Eduard Taaffe's conservative-Slav Iron Ring government in Austria (1879-1893), a similar process towards opposition and national defence was occurring amongst German speakers in Austria. Taaffe's ministers were taken from conservative, Czech and Polish ranks while the Austro-German liberals were confined to vigorous protests in parliament and at public meetings. In these circumstances the Deutscher Schulverein founded in Vienna (DSV) quickly became the most important association dedicated to the defence of Deutschtum. Founded on 2 July 1880 by a group of young nationalists, the DSV had phenomenal success and within three years had 100,000 members and 761 local organisations covering all the major German-speaking Austrian cities. Soon almost every public figure in Austrian-German life was compelled to display prominently their membership and activity in the DSV. ${ }^{38}$ Austrian law prevented the DSV interfering in the affairs of Hungary, especially for such a sensitive region as Transylvania, nevertheless there was evident interest in the Transylvanian Saxon situation from among the members of the various overlapping German nationalist

\footnotetext{
${ }^{37}$ For some background see F. Gottas, 'Zur Nationalitätenpolitik in Ungarn unter der Ministerpräsidentschaft Kálmán Tiszas’, Südostdeutsches Archiv 17/18 (1974-75), pp. 89-96.

[Type text]
} 
associations in Austria. ${ }^{39}$ In early 1881 there was intense communication between the DSV and certain groups within Imperial Germany about setting up a similar association in Berlin. ${ }^{40}$

Already a number of informal groups in Imperial Germany had expressed concern at the condition of German-speaking communities in Austria and Hungary. Heinrich Treitschke and Theodor Mommsen at the University of Berlin led various groups concerned with so-called Auslandsdeutschen, while in Leipzig an association for trade and German interests in foreign lands was having regular meetings under the leadership of Ernst Hasse, who would later gain prominence as the leader of the Pan-German League. As early as November 1880 a related Zentralverein für Handelsgeographie based in Berlin was in contact with the DSV arguing for an active, expansionist German colonial policy. At a local meeting in Berlin on 23 June 1881 the central figure, Julius Falkenstein, spoke of the 'stormy actions of the Hungarians and Czechs against the German population'. ${ }^{41}$

The momentum to form an association which would encompass the various groupings led to the foundation of the ADS in Berlin on 15 August 1881. Prominent

\footnotetext{
${ }^{38}$ Even the arrogant, Anglophile Ernst von Plener, son of a Minister and from a family of bureaucrats, defended the role of the Deutscher Schulverein when he made political speeches. For example, E. Plener, Reden von Ernst von Plener 1873 bis 1910 (Stuttgart, 1911), pp. 514 and 652.

${ }^{39}$ For example see Zur Lage der Siebenbürger Sachsen. Flugblatt des Deutschen Vereins in Wien (Munich, 1878), which contains a strongly German nationalist speech from Victor Capesius and a copy of an article from the Neue Freie Presse which conceded that with the 1867 Ausgleich the Saxons had been sacrificed to Hungarian dominance.

${ }^{40}$ The link is outlined in W. Wattenbach, Der Allgemeine Deutsche Schulverein zum Schutz bedrängter Deutscher im Ausland. Seine Ziele und Bestrebungen (Berlin, 1884).

${ }^{41}$ Quoted in Weidenfeller, $A D V, 155$. For a general background to the formation of the ADS see Wattenbach, Der Allgemeine Deutsche Schulverein, pp. 3-31, R. Chickering, We Men Who Feel Most German. A Cultural Study of the Pan-German League, 1886-1914 (Boston, 1984), pp. 29-33, G. Haude and K. Poßekel, 'Verein für das Deutschtum im Ausland (VDA)' in Dieter Fricke, ed., Die bürgerlichen Parteien in Deutschland. Handbuch der Geschichte der bürgerlichen Parteien und anderer bürgerlicher Interessenorganisationen vom Vormärz bis zum Jahre 1945 (Leipzig, 1970), pp. $716-29$ and especially Weidenfeller, $A D V$, pp. 140-65.
}

[Type text] 
professors such as Wilhelm Wattenbach and Wilhelm Groos, both visitors to

Transylvania in 1875, were involved in the ADS from the outset. Karl Wolff was invited

to Berlin to meet the board of the ADS and he expressed a desire to deepen economic ties though there was no mention of direct aid. Perhaps Wolff was cautious because of the Hungarian government's sensitivity to outside interference. It was not surprising that the first open letter from the ADS, which appeared in November 1881, made specific reference to the position in Transylvania. The phrasing is indicative of the ADS's thinking.

Above all, it is the Germans in Hungary and Transylvania who need our help. Despite legal guarantees for the equality of languages, the dominant Magyar minority has for the last few years worked seriously to destroy German education in the lands of the Hungarian crown ... the Magyars should thank the Germans for their freedom from Turkish domination as well as the light of European culture that has reached the Hungarian lands ... the organisation of the Allgemeiner Deutscher Schulverein would like to be in the position to build a shield, which would operate wherever modern barbarism threatens the areas of German culture (Bildung). ${ }^{42}$

The trope of honest, universal German culture working to civilise the wilds of the barbaric East reflected the mindset of the activists and formed a constant refrain in the German-speaking populations of Central and Eastern Europe.

The ADS became a focal point in a concerted effort to rouse German public opinion in defence of the Transylvanian Saxons and other German speakers in Hungary.

On 7 December 1881 one of the ADS's prominent leaders, Robert Jannasch, called on the German press and politicians to help the plight of the Saxons.

The meeting therefore asks the German press as well as the parliamentarians of all German parties to stand up for the benefit of the Germans in Hungary and Transylvania against the threat of Magyarization. This is necessary because of the duty to a German branch (Stamm) as well as our own national pride. ${ }^{43}$

\footnotetext{
${ }^{42}$ Quoted in Weidenfeller, $A D V$, p. 172.

${ }^{43}$ Quoted in Barta and Bell, Geschichte der Schutzarbeit am deutschen Volkstum, p. 128.
}

[Type text] 
Already, there had been an important article in the 1881 Preussische Jahrbücher on the Hungarian Germans (with a case study of the Saxon town, Mühlbach) updating the readers about the Magyarization process of recent years. ${ }^{44}$

The appearance of a lengthy brochure from a Professor at Heidelberg, Rudolf Heinze then stoked the flames. In his brochure, Heinze described the process of Magyarization - the replacement of officials and teachers, the pressure placed on German language and education, the attacks against the Universitas Saxonum and selfautonomy, among other actions - before extolling the achievements of the Germanspeaking population, especially the foundation of towns and the building of civilisation through German culture and hard work. ${ }^{45}$ In a systematic exposition of various laws and regulations, Heinze attempted to prove that Magyarization was the absolutely dominant central point of the Hungarian state. ${ }^{46}$ In conclusion, Heinze asserted his credentials as an academic stating that he had used a scholarly approach and had tried to show things as they were. He cautioned that the overwhelming power of the state coupled with Magyar race fanaticism constituted a dangerous combination. Finally, he finished by appealing for Germans to help their Saxon brothers as a matter of honour. ${ }^{47}$

The ADS then published a brochure under the name of Karl Ludolf, in fact written by Johann Wolff - a Rector in Mühlbach, Transylvania - which went over much

\footnotetext{
${ }^{44}$ [Anon.], 'Die Deutschenhetze in Ungarn (Aus Ungarn)' in H. Treitschke, ed., Preussische Jahrbücher 47 (1881), pp. 41-8. The author was probably Georg Daniel Teutsch who had friendly relations with the editor Heinrich Treitschke. See Vlaicu, Briefe an Georg Daniel Teutsch, p. 189. See also G. Rath, Siebenbürgen Reisebeobachtungen und Studien (Nach Vorträgen für wohlthätige Zwecke gehalten zu Duisburg am 13 November 1878 und zu Bonn am 3 Februar 1879) (Heidelberg, 1880).

${ }^{45}$ R. Heinze, Hungarica. Eine Anklageschrift (Freiburg, 1882), pp. 25-50

${ }^{46}$ Ibid, p. 91.

${ }^{47}$ Ibid, pp. 122-6.

[Type text]
} 
of the same territory as Heinze's. ${ }^{48}$ Throughout the brochure, Johann Wolff used such terms as 'Magyar tyranny of language' [magyarische Sprachtyrannei] and the 'Magyar Inquisition' [die magyarische Inquisition] as well as the typical 'German hard-work and perseverance' [deutscher Fleiss und deutsche Ausdauer]. ${ }^{49}$ The brochure contained an introduction from Julius Falkenstein of the ADS and in an appendix at the end published the association's statutes. The first paragraph of the statutes notes that ' $[\mathrm{t}] \mathrm{he}$ "DeutscheSchulverein" has the purpose of supporting Germans outside the Reich to retain their Deutschtum and to strengthen their attempts to remain German or to become German again' ${ }^{50}$ The statutes went on to mention specific aid such as the erection of schools and libraries, the provision of German books, writings and teachers. ${ }^{51}$

A separate inflammatory brochure, not directly on the Transylvanian Saxons, but dealing with the general situation in the Habsburg Monarchy appeared in Munich around this time. ${ }^{52}$ This prompted a vigorous, specific reply defending the Magyar viewpoint, especially the status of Hungary as a civilised European nation. ${ }^{53}$ Adding further fuel to the fire, a lecture given by Wattenbach in 1870 was republished by the ADS with a new preface reviewing the recent wave of publications and a sober afterword describing the imminent Mittelschule law. ${ }^{54}$ Yet another lengthy brochure appeared in 1882, this one

\footnotetext{
48 [J. Wolf], Der Sprachen-und Völkerkampf in Ungarn. Ein Bericht- und Mahnwort an das deutsche Volk (Leipzig, 1882). The attribution is found in F. Teutsch, Siebenbürgische Geschichte für das sachsische Volk, Vol. 4, p. 86.

${ }^{49}$ [Wolf], Sprachen-und Völkerkampf, pp. 26, 28 and 76.

${ }^{50}$ Ibid, p. 86. See also Statuten des Allgemeinen Deutschen Schul-vereins zur Erhaltung des Deutschtums im Auslande (Berlin, [1881?]).

${ }^{51}$ Ibid.

52 J. Sepp, Ein Volk von zehn Millionen oder Der Bayernstamm, Herkunft und Ausbreitung über Oestreich, Kärnthen, Steyermark und Tyrol. Kampfschrift wider Czechen und Magyaren (Munich, 1882).

${ }^{53}$ K. Tóth, Vertheidigung der Ungarn gegen Prof. Dr. Johann Sepp's Angriffe. Als Erwiderung auf die im Werke 'Ein Volk von zehn Millionen oder der Bayerstamm. Eine Kampfschirft gegen Czechen und Magyaren' erhobenen Anklagen (Pressburg, 1884), pp. 12-13.

${ }^{54}$ W. Wattenbach, Die Siebenbürger Sachsen. Ein Vortrag (Munich, 1882).

[Type text]
} 
from the hand of C. F. Maurer with a preface from Wattenbach. ${ }^{55}$ The sentiments in this brochure mirrored those of the ADS and the now voluminous German-language literature on the Transylvanian Saxon dilemma. ${ }^{56}$

Such negative sustained interest in their country could only provoke the Magyars, who were more accustomed to fighting Vienna's interference and thus receiving the approbation of European public opinion. Hungary’s relations with Imperial Germany had been, in general, very good. Indeed one of Hungary's greatest statesmen, Gyula Andrássy, had negotiated the Dual Alliance with Bismarck. For a number of reasons the Dual Alliance proved a natural fit. First, there were many German speakers spread throughout the Monarchy. Second, Bohemia and the Alpine Lands had been part of the Holy Roman Empire for centuries, thus a certain historical affinity had always existed with the various German-speaking lands. This was reflected in the election of representatives to the 1848 Frankfurt Parliament from Bohemia and the Alpine lands and the associated idea of a Großdeutschland. Third, as mentioned previously, during the mid to late nineteenth century there was a general perception that a great confrontation between civilisation and barbarity would occur, thus determining the course of history. This powerful mix of enlightenment concepts (levels of civilisation), historical teleology (primarily inspired by Hegel but also expressed in terms such as 'destiny' and 'fate'), ethnic and racial thinking (given impetus by Herder) and grand Darwinist inspired theories of evolution provided the background to much decision making. ${ }^{57}$ For example, amongst the multitude of complex reasons for the installation of the 1867 dualist system,

\footnotetext{
${ }^{55}$ C. F. Maurer, Die Besitzergreifung Siebenbürgens durch die das Land jetzt bewohnenden Nationen (Berlin, 1882).

${ }^{56}$ Ibid.

[Type text]
} 
one of the underlying bases was the idea of the Germans and Magyars as Staatsvölker; in other words, civilised peoples who deserved to oversee the progress of state, society and culture. These sentiments were evident in many Transylvanian Saxon pamphlets, which argued for common interests of the Saxons and Magyars to counter the threat from the Slavs and, less often mentioned, the Romanians. ${ }^{58}$ There were understandable concerns in Magyar circles that elements within its ally and 'natural' partner were criticising Hungarian domestic policies. The response was swift.

Ambros Neményi in the New Year's edition of the Ungarische Revue laid out the Magyar arguments. Neményi was provoked to respond, he explained, because a number of famous professors had signed the ADS's open letter. ${ }^{59}$ He traced the agitation to a small clique among the Transylvanian Saxons since other Germans in Hungary were not interested in the ADS's activities and were, in fact, assimilating into Hungarian culture and society. ${ }^{60}$ This Saxon clique, argued Neményi, had misled the ADS and the German public with false information. For example, Hungary had a free press which would allow discussion of the ADS's letter. Would a similar letter from a German socialist or a French

\footnotetext{
${ }^{57}$ For the coalescence of these factors in Imperial German thinking around the mid-nineteenth century see Vejas Gabriel Liulevicius, The German Myth of the East. 1800 to the Present (Oxford, 2009), pp. 71-97.

${ }^{58}$ For example, Guido von Baußnern, a prominent Saxon politician close to Hungarian circles, argued for co-operation between the Germans and Hungarians on the basis of a common cultural mission. [G. Baußnern], Das Erwürgen der deutschen Nationalität in Ungarn. Denkschrift aus Siebenbürgen mit Vorwort von Franz von Löher (Munich, 1874), pp. 56-9 and idem, Deutschland und Österreich-Ungarn. Abhandlungen, Reden und Briefe 1868-1889 (Leipzig, 1890), pp. 12-25 and 47-57. This issue has been discussed, among much else in German-Hungarian relations, in R.J.W. Evans, 'Hungary and the German Lands in the Nineteenth Century' in Evans, Austria, Hungary, and the Habsburgs, pp. 228-41. From the German perspective see also W. Mommsen, 'Österreich-Ungarn aus der Sicht des deutschen Kaiserreichs' in H. Rumpler, ed., Innere Staatsbildung und Gesellschaftliche Modernisierung in Österreich und Deutschland 1867/71-1914 (Munich, 1991), p. 208.

${ }^{59}$ A. Neményi, Hungaricae Res. Ein Commentar zu dem Aufruf des 'Allgemeinen Deutschen Schulvereins' in Angelegenheit der Unterdrückung der Deutschen in Ungarn und Siebenbürgen (Budapest, 1882), p. 5. This originally appeared in the 1 January 1882 edition of the Ungarische Revue.

${ }^{60}$ Ibid, pp. 6 and 32.

[Type text]
} 
nationalist in Alsace have been possible?, asked Neményi. ${ }^{61}$ In addition, Neményi queried whether the ADS had read the School laws which respected the 15 different languages in Hungary while instigating the study of a necessary common language (Magyar), just as in Belgium or Posen. ${ }^{62}$ In fact, Neményi continued, many German speakers wanted to learn Magyar and there was an informal exchange system with Magyar families to facilitate this. ${ }^{63}$ He also challenged the notion that the Germans had freed Hungary from the Turks. Rather, Neményi countered, wasn't it the Hungarians who had for centuries protected the Germans (and Europe) from the Turks! ${ }^{64}$ At the root of Neményi's vigorous defence was the assertion that Hungary was only doing what all Western European countries were doing; namely nation-building and state consolidation. ${ }^{65}$ This meant that outdated Saxon privileges had to be reduced or abolished and the Magyar language learnt by all Hungarian citizens. The only people who opposed this, concluded Neményi, were the Transylvanian Saxons. They were causing a disturbance to both the Dual Alliance and the underlying alliance of German and Hungarian peoples (Völker). ${ }^{66}$

The fundamental lines of battle had become clear. First, there was the disagreement over rights, laws and the requirements of a modern cultured state. The Magyars argued for a standardised administrative and legal system, whereas most Saxons continued to insist on their historical and natural rights as guaranteed by various promises and the Nationality Law of 1868. Second, the place of the Magyars and Germans in

\footnotetext{
${ }^{61}$ Ibid, p. 7.

${ }^{62}$ Ibid, pp. 11-14. Posen was often mentioned by Magyar commentators since Imperial Germany had strong nationalizing policies in this former region of Poland, including Bismarck's famous Prussian Settlement Commission set up in 1886.

${ }^{63}$ Ibid, p. 18.

${ }^{64}$ Ibid, pp. 25-6.

${ }^{65}$ Ibid, pp. 30-1.

[Type text]
} 
Western European history was heavily disputed. The Magyars conceived of themselves as the noble defenders of Western Christendom, the Eastern outpost of civilisation and culture. The Transylvanian Saxons and their German supporters, however, emphasised their own contribution to centuries of Christian defence (however ambiguous this really was in Transylvania's case), arguing for recognition of their role on the frontier of Western civilisation.

The debate escalated when it breached the walls of the Hungarian parliament. Ottó Herman, a former zoologist in the Transylvanian Museum and radical Independent nationalist parliamentarian, called into question a budget allocation of 200,000 florins for the Transylvanian Saxons. Herman immediately mentioned the ADS's actions in Germany as being a direct attack against the Magyar nation. ${ }^{67} \mathrm{He}$ openly questioned the loyalty of the Transylvanian Saxons, citing a previous comment by the Saxon politician Guido von Baußnern that the Honvéd uniform was inconsistent with Deutschtum, as well as Karl Wolff's use of the word 'Magyar gluttony' [Magyarenfresserei]. Herman continued in the same vein. In particular the unification of Germany in 1871, according to Herman, had shown:

that the victory of the great German nation was desired by countless sons of Saxon nationality, [who also wanted] to lay down their Hungarian citizenship and [despite being] in the territory of the Hungarian Crown feel as a part of the great German nation, and therefore to found a State within a State... ${ }^{68}$

Herman added that the scandal being played out in the German press and public opinion was against all laws and justice, thus warranting official action from the Hungarian

\footnotetext{
${ }^{66} \mathrm{Ibid}$, pp. 32-5.

${ }^{67}$ The whole debate is published in Die Debatte vom 27 Januar 1882 im ungarischen Abgeordnetenhaus über die deutsche Bewegung (Hermannstadt, 1882).

${ }^{68}$ Ibid, 3. See also Siebenbürgisch-Deutsches Tagesblatt, 30 January 1882 'Debatte über die Bewegung in Deutschland'.
}

[Type text] 
government.

Herman's speech could not fail to provoke the Saxon representatives. First, Karl Wolff, giving his maiden speech in the Hungarian parliament, spoke and defended the movement in Germany. The Saxons, he said, merely wished to stay true to their nationality. ${ }^{69}$ Josef Gull, the representative from Großau, welcomed the German nation's desire to help and defended Heinze's claims of Magyarization. ${ }^{70}$ For his forthrightness, Gull was asked by the President of Parliament to retract his remarks, whereupon Gull switched from speaking Magyar to his native German. He repeated his assertions of Magyarization and defended his loyalty to his nationality. ${ }^{71}$ Herman replied that he did not want to destroy the ADS, simply to tell people the real state of affairs and paralyse the ADS's effect on public opinion. ${ }^{72}$

The Hungarian Prime Minister Kálmán Tisza responded in a relatively cool and pragmatic manner. The government, he said, will do its duty to combat the various antiHungarian pamphlets. He also pointed out that there were many German speakers who were good Hungarian patriots, as opposed to the Transylvanian Saxons. He was undoubtedly referring to the scattered German communities throughout Hungary who did not have long traditions of privileges and were generally friendlier towards the Hungarian state idea. Finally, Tisza noted that there was little chauvinism in Hungary, especially compared to what was happening in Posen and Alsace-Lorraine. ${ }^{73}$ A member of the government party, Emerich Zvanka, in a neat reversal, then immediately proposed a 200,000 florin fund to fight the negative propaganda in Germany. Blasius Orban

\footnotetext{
${ }^{69}$ Ibid, p. 4.

${ }^{70}$ Ibid, pp. 5-6. Großau/Cristian/Kereszténysziget.

${ }^{71}$ Ibid, pp. 7-9.

${ }^{72}$ Ibid, p. 9.
}

[Type text] 
continued in this vein and highlighted the Magyars' historical role in protecting Germany from the barbaric, Asiatic hordes. ${ }^{74}$ After further exchanges with the Transylvanian Saxon representatives, Tisza summed up the government's position by affirming 'that we nevertheless are all of one mind; that Hungary belongs to the Magyars and there can only be a Magyar state (general sustained acclaim and applause). ${ }^{.75}$

The German language press in Hungary reflected the disparate views both within the Transylvanian Saxon community and the wider German-speaking Hungarian population. The Pester Lloyd - based in Budapest and under the influence of the Hungarian government - complained of the German 'schoolmaster illness' (whereby the Germans could not resist interfering and passing judgment on other countries) and extolled the virtues of Hungary's liberal institutions. ${ }^{76}$ Another Budapest-based paper, the Pester Journal, restricted its coverage to a reproduction of the parliamentary speeches, as did the venerable Preßburger Zeitung, published in Bratislava. ${ }^{77}$

Among the Saxon papers, the conservative Hermannstädter Zeitung expressed a conciliatory stance, reflecting a softening towards the Hungarian government by some within the 'Old Saxon' ranks. In a lengthy comment on the parliamentary debate, the editors isolated the two issues involved: first, the agitation against Hungary from the German Reich and, second, the implications for Deutschtum within Hungary. ${ }^{78}$ The newspaper showed concern that the Germans might use beautiful phrases in support of

\footnotetext{
${ }^{73}$ Ibid, pp. 10-15.

${ }^{74}$ Ibid, pp. 17-20.

${ }^{75}$ Ibid, p. 47.

${ }^{76}$ Pester Lloyd, 21 February 1882, Morning edition.

${ }^{77}$ For example see Pester Journal, 16 Februar 1882 'Aus dem Reichstage' and Preßburger Zeitung, 16 Februar 1882 'Pfui'. Preßburg/Pozsony/Bratislava.

${ }^{78}$ Hermannstädter Zeitung (HZ), 7 February 1882 'Ein Nachtrag zur Debatte im ungarischen Reichstage vom 27 Januar'.
}

[Type text] 
the Saxons and then let them down. ${ }^{79}$ In fact, the Hermannstädter Zeitung declared no sympathy at all for the ADS, describing the Saxons as good citizens (Staatsbürger) and a quiet, peaceful people (ruhiges Volk). There should be no fear of Magyarization since whatever happened the Saxons would remain German. This pragmatic approach was highlighted in their conclusion:

And if we hold fast to our German nationality, we are not lesser Hungarian citizens, because we know that for the Saxons, especially for political and cultural matters, the word 'extra Hungariam non est vita' [outside of Hungary there is no life] applies. ${ }^{80}$

In a subsequent edition the Hermannstädter Zeitung was extremely critical of Heinze's pamphlet describing it as 'literary impertinence' [literarische Frechheit] and its author as a 'malicious babbler and slanderer' [heimtückischen Schwätzer und Verleumder]. ${ }^{81}$

At the other end of the Saxon political spectrum was the Kronstädter Zeitung which used strong language against the Hungarian government and its Magyarization policy. As already outlined, the Saxon political circles in Kronstadt were moving towards opposition since the railway issue had been resolved, increased migration was eroding Saxon influence and the institutions of the Hungarian state increasingly asserted Magyar dominance.

The dominant nation of the land suffers from the passionate hate of Germans, suffers from the passion of Hungarian national selfishness ... The Magyar hates the German! Why? Because the Germans want to remain, because the Magyar is afraid of the imaginary spectre of Germanisation. ${ }^{82}$

The Kronstädter Zeitung continued in a similar vein a few days later in response to Herman's parliamentary posturing and referred to the promises made in 1868: '[i]n a

\footnotetext{
${ }^{79}$ Ibid.

80 Ibid.

${ }^{81} \mathrm{HZ}, 17$ February 1882 'Politische Uebersicht'.

${ }^{82}$ Kronstädter Zeitung (KZ), 25 January 1882 'Wahrheit und Lüge'.
}

[Type text] 
cultured state promises and rights must be respected! Or does our [Hungarian] Fatherland want to somehow exclude itself from educated Europe? ${ }^{83}$ In a summary of their point of view, the Kronstädter Zeitung published an editorial entitled 'The Situation of the Saxons', which pleaded for justice [Gerechtigkeit]. The specific demands were familiar: autonomy; use of the German language in church, school and with the state authorities; and the traditional property rights of the Universitas. ${ }^{84}$ Was this the talk from enemies of the state?, asked the Kronstädter Zeitung. Kronstadt was gradually becoming the centre of more assertive German nationalist politics.

An intermediate position was taken by Karl Wolff's Siebenbürgisch-Deutsches Tagesblatt, which had the closest contact with the ADS. While the SiebenbürgischDeutsches Tagesblatt did not use the emotive language of the Kronstädter Zeitung, it clearly welcomed the ADS's actions and encouraged a balanced defence of Saxon rights and privileges. In its first extended comment on the parliamentary debate (the Siebenbürgisch-Deutsches Tagesblatt had reprinted all the speeches over the preceding week), the ADS's intentions were defended ${ }^{85}$ The Siebenbürgisch-Deutsches Tagesblatt continued to argue that being German speakers in Hungary did not mean disloyalty towards Hungary: 'one thing we have achieved: we have defended our rights by all legal means! ${ }^{86}$ Throughout the controversy, the Siebenbürgisch-Deutsches Tagesblatt reported on meetings and expressions of support from the greater German-speaking world Zürich, Bern, Karlsruhe, Eberbach, Heidelberg, Leipzig, Munich, Mannheim, the Norddeutsche Allgemeine Zeitung - giving the impression of a broad movement

\footnotetext{
${ }^{83} \mathrm{KZ}$, 28 January 1882 'Recht und Gesetz'.

${ }^{84} \mathrm{KZ}, 11$ February 1882 'Die Lage der Sachsen'.

${ }^{85} S D T, 10$ February 1882 'Nachwort zu den Verhandlungen des ungarischen Reichstages vom 27 Januar 1882'.
}

[Type text] 
encompassing much of Germany's educated public. ${ }^{87}$ Thus the three contrasting views of political tactics - co-operation, opposition and principled defence - were all represented in the Saxon press.

Ottó Herman did not let the matter rest. He followed his 27 January speech with an official parliamentary interpellation on 15 February reiterating his belief that the real goal of the ADS movement was directed against the Hungarian nation. ${ }^{88}$ Herman listed the various recent German publications including Heinze's, Ludolf's and a number sponsored by the ADS (Wattenbach's contributions, in particular, were highlighted). Once again, Herman demanded official government action to counter the wave of Reich German publications in support of German speakers in Hungary. In his reply, Tisza was more circumspect than before, stating that the law was equal for everybody and that the Hungarian government need only tell the truth in the matter. Indeed, he stressed that the growing scandal was a private, societal matter which should not impact on diplomatic relations with Imperial Germany. Tisza was clearly wary of provoking Bismarck and was awaiting news from Berlin.

Following Herman's remarks in January there had been considerable diplomatic communiqués from all sides in an attempt to assess the respective positions. The German General Consul in Budapest, Wilhelm von Thielau, had immediately sent a report of the parliamentary proceedings to Berlin where Bismarck was taken aback by Tisza's

\footnotetext{
86 Ibid.

${ }^{87}$ SDT, 30 Januar 1882 'Deutscher Schulverein'; SDT, 3 Februar 1882 'Die "Norddeutsche Allgemeine Zeitung” und das Deutschtum in Ungarn'; SDT, 8 Februar 1882 'Verein zum Schutz deutscher Interessen im Ausland'; SDT, 16 Februar 1882 'Deutscher Schulverein'; SDT, 18 Februar 1882 'Deutscher Schulverein' and SDT, 6 März 1882 'Aus Leipzig'.

${ }^{88}$ See the report in SDT, 18 February 1882 'Otto Hermann's Interpellation im ungarischen Abgeordnetenhause über die Bewegung in Deutschland'.
}

[Type text] 
reference to Posen. ${ }^{89}$ The German ambassador in Vienna, Prince Heinrich von Reuß VII, asked Andrássy (who, while no longer Foreign Minister, still had much influence in diplomatic circles) about the possible implications for the Dual Alliance. The current Foreign Minister Gustav Kálnoky, who was born in Moravia to a family with Transylvanian Székely roots, privately apologised to Reuß. Tisza’s measured reply in February obviously reflected the delicate state of relations between the two allies. For Bismarck, Hungary was an integral part of the alliance system which protected Germany's vulnerable position in the heart of Europe. He was therefore pleased when the ADS's actions did not find much resonance in Imperial Germany's press. Practically, it was difficult to provide official help to the Transylvanian Saxons without harming the Dual Alliance and unduly injuring Habsburg and Hungarian pride. ${ }^{90}$

In the Transylvanian press, the Kronstädter Zeitung had already made its position clear and restricted its comments to the ironic observation that Herman in fact came from a German family in the Zips. ${ }^{91}$ The Siebenbürgisch-Deutsches Tagesblatt kept the debate alive by commenting on the growing publications. On 28 February it refuted both Nemenyi's pro-government articles in the Hungarian-German press (referring to him as Abraham Neumann, presumably hinting at a German-Jewish background) and another brochure entitled 'Das Deutschtum in Ungarn von einem Stock-Magyaren'. ${ }^{92}$ The Magyar arguments of Saxon disloyalty to the Hungarian state idea and the need for a modern, liberal legal framework were rejected by the Siebenbürgisch-Deutsches

\footnotetext{
${ }^{89}$ Weidenfeller, VDA, pp. 182-3. Bismarck clearly did not welcome comment on his own government's nationalizing policies in Posen.

${ }^{90}$ Ibid, p. 195.

${ }^{91} \mathrm{KZ}, 18$ February 1882 'Zur Tagesgeschichte'.

${ }^{92}$ SDT, 28 February 1882 'Zur Aufklärung' and [Anon.], Das Deutschtum in Ungarn. Einige Worte zur Aufklärung von einem Stock-Magyaren (Berlin, 1882).

[Type text]
} 
Tagesblatt as misleading since the 1868 Nationality Law had not been respected and the 1876 laws had broken all promises of Saxon autonomy. Heinze's brochure, which had been a major reason for the current scandal, was - despite some acknowledged errors defended. ${ }^{93} \mathrm{~A}$ few days later the highly respected Augsburger Allgemeine Zeitung was invoked as commenting positively on Heinze's pamphlet.

The first Correspondenzblatt des Deutschen Schulvereins zu Berlin appeared amidst the furore in February 1882. A full transcript of the January parliamentary debate occupied the first forty pages while a lecture given by Wattenbach in Dresden was reported, including words that echoed the sentiments of many Transylvanian Saxons (especially his acquaintance Karl Wolff): 'The whole hate only stems from the Saxons while at the same time being good Hungarian citizens - not preparing to sacrifice their Deutschtum - unlike, unfortunately, some other German-Hungarians. ${ }^{94}$ The next issue also focussed on the situation in Hungary and contained an open letter, drafted by Rudolf Heinze, in response to the Magyar accusations. The ADS, the letter explained, only intended to help the Saxons in protecting their language and culture as well as their autonomy in churches and schools. ${ }^{95}$ There was an appeal to the Hungarian liberal government not to turn the Hungarian state idea into a monopoly of one race in a country of many nationalities. Once again, echoing comments made by Karl Wolff, the ADS agreed that Hungarian state feeling (ungarisches Staatsgefühl) could exist in harmony with the German language and people (Volkstum) ${ }^{96}$

At the same time, amongst Hungary's German speaking population, a series of

\footnotetext{
${ }^{93}$ SDT, 4 March 1882.

${ }^{94}$ Correspondenzblatt des Deutschen Schulvereins zu Berlin, No. 1, February 1882.

${ }^{95}$ Ibid, p. 4. See the attribution in Barta and Bell, Geschichte der Schutzarbeit am deutschen Volkstum, p. 129.
}

[Type text] 
public demonstrations were organised across the country; some in favour of the ADS's offer of help and some against. Beginning with a meeting in Pancsova, a town in the Banat region, on 19 March (against), there were further resolutions and meeting throughout the summer. Towns against any ADS aid were Leutschau (2 April), Preßburg (4 April), Klausenburg (5 April), Pest (9 April), Csatad (10 April), Käsmark (11 April), Temesvar (14 April), Budapest (1 May). Towns in favour of ADS aid were concentrated on Saxon territory: Hermannstadt (16 April), Kronstadt (16 April), Großau (7 May), Mediasch (7 May), Bistritz (7 May), Broos (7 May), Heltau (14 May), Reps (18 May), Agnetheln (29 May), Reußmarkt (29 May), Arkeden and Meburg (30 May), Schäßburg (11 June) and Leschkirch (11 June) ${ }^{97}$ In its reports on the demonstrations, the Siebenbürgisch-Deutsches Tagesblatt implies that Hungarian bureaucrats and municipal authorities were behind the initial wave of resolutions rejecting any help from the ADS. ${ }^{98}$ The editor, Karl Wolff, felt compelled to comment on the initial demonstrations against the ADS, which, he alleged, were instigated by 'Magyars with German names' ${ }^{99} \mathrm{He}$ immediately stated that he did not agree with the Pancsova resolution since no civilised state would want to destroy its citizens' sense of belonging [Stammesangehörigkeit]. ${ }^{100}$

The Kronstädter Zeitung concentrated on the area around Kronstadt and in an article appearing on 13 April 1882 (three days before the Kronstadt meeting), Adolf Zay appealed to the voters for justice and peace which would allow the development of the

\footnotetext{
${ }^{96}$ Ibid, p. 5.

${ }^{97}$ Since this is a long list of towns which do not reappear in the article I have omitted the Hungarian and Romanian alternative town names.

${ }^{98}$ SDT, 22 March 1882 'Demonstrationen gegen den "Deutschen Schulverein"'.

${ }^{99}$ SDT, 23 March 1882 'Die Resolution der Pancsovaer Bürger gegen den "Deutschen Schulverein"”. This rejection of the Schulverein's offer and the existence of modern constitutional rights in Hungary were commented on by the international press. See The Times, 28 March 1882 'Austria-Hungary' and 12 April 1882 'Hungary'.

${ }^{100}$ Ibid.

[Type text]
} 
German language, education and civilisation within the framework of the Hungarian state. ${ }^{101}$ Just one day before the Kronstadt meeting, the Kronstädter Zeitung endorsed Zay's article, welcoming the sentiment and describing Zay as a true advocate of German education and culture (Bildung und Gesittung). ${ }^{102}$ In the edition immediately after the local meeting, the Kronstädter Zeitung printed the resolution passed unanimously by 800 people present. ${ }^{103}$ The resolution began by asking whether the Hungarian state would be built in accordance with the principles of European state building and legal development, or in the spirit of racial hatred. A unified, integrated Hungarian state was not wanted, the resolution continued, and the ADS's actions were not inconsistent with international or Hungarian laws. ${ }^{104} \mathrm{~A}$ transcript of the speeches was published over the next few days but both in the Kronstädter Zeitung and the Siebenbürgisch-Deutsches Tagesblatt, comment on the incident subsided over the summer, partly due to the natural course of events but also with the realisation that the Hungarian or German governments were now involved.

In a summary of the meetings and of the moderate Siebenbürgisch-Deutsches Tagesblatt position, the brochure Die Deutschen in Ungarn und Siebenbürgen und der 'Deutsche Schulverein' appeared at the end of June. After a short introduction to the situation and a detailed description of each meeting, including transcripts of the speeches, a tentative conclusion was reached. First of all, there was surprise expressed at the storm surrounding the ADS, since it was a private organisation helping in cultural and educational matters. ${ }^{105}$ Secondly, the Zipser Germans' opposition to the ADS was

\footnotetext{
${ }^{101} \mathrm{KZ}, 13$ April 1882 'An die sächsischen Wähler der vier Reichstagswahlkreise des Kronstädter Komitates'.

${ }^{102} \mathrm{KZ}, 15$ April 1882 'Gruß an Herrn Adolf Zay'

${ }^{103} \mathrm{KZ}, 17$ April 1882 'Resolution für den deutschen Schulverein

${ }^{104}$ Ibid.

${ }^{105}$ Die Deutschen in Ungarn und Siebenbürgen und der 'Deutsche Schulverein', p. 187.

[Type text]
} 
attributed to their different past. ${ }^{106}$ The Zipser Germans, according to the brochure, had no political or communal unity - not having a tradition of autonomy - whereas the Transylvanian Saxons could look to the Universitas as a symbol of community. The difference between the Saxons and the other German-speaking Hungarians (who were more widely scattered, less entrenched in tradition and more conducive to the Hungarian state idea) was made especially stark by the demonstrations. Thirdly, the Magyar press had focussed on the diplomatic implications, perceiving the incident as a matter for the German and Hungarian governments, however for the Transylvanian Saxons, and indeed for the German-speakers in Hungary, the real issue was deeper: did the Germans have a right to remain Germans in this land? ${ }^{107}$ Finally, as a result of the events, at the very least the Saxons had become more aware of the situation, or in the words of the author of the brochure: "it is the first time for a long time that the Germans there have been moved to speak as Germans." 108

The Hungarian government was most concerned, as the brochure mentioned, with the German government's response and the effect on European public opinion. A change to the overall policy of Magyarization was not in question but the Hungarian government was concerned about relations with Germany and general European opinion. Tisza wrote to Kálnoky on 31 March 1882 about his concerns and Kálnoky replied on 3 April 1882 promising to try and spread an official Hungarian brochure through the consulate and other diplomatic channels. ${ }^{109}$ Kálnoky did not regard Transylvanian Saxon political

\footnotetext{
${ }^{106}$ Ibid, p. 188.

${ }^{107}$ Ibid, p. 189.

${ }^{108}$ Ibid, p. 190.

${ }^{109}$ See Gottas, Ungarn im Zeitalter des Hochliberalismus, p. 196. B. Jelavich, 'Foreign Policy and the National Question in the Habsburg Empire: A Memorandum of Kálnoky', Austrian History Yearbook 6-7 (1970-71), p. 152.
}

[Type text] 
activity as a serious threat to the Monarchy or its foreign policy. Indeed, in the region, he was more concerned with possible agitation and obstruction by the recently declared Kingdom of Romania and the effects on Transylvanian Romanians. ${ }^{110}$ On 9 November the long-awaited Hungarian government brochure in response to Heinze's pamphlet appeared. Entitled Dr. Heinze's Anklageschrift 'Hungarica' im Lichte der Wahrheit, the book was remarkably restrained in its approach. It first outlined Heinze's criticisms of Magyarization and his arguments for a polyglot state, and then proceeded to refute each of Heinze's points with a wealth of statistics and facts. In fact, it reads exactly as it is: a bureaucratic product of a governmental committee. ${ }^{111}$ Its lack of passion and dry factual manner was perhaps adopted in a calculated attempt to drain the emotion from the debate, somewhat akin to Tisza's measured reply to Herman's interpellation in February. Heinze responded in similar manner with an unemotional, factual ADS sponsored brochure. ${ }^{112}$

Tisza and the Hungarian government could not afford to provoke either the German government or public as they were already in the middle of preparing a Mittelschule bill which would enforce state control over education, require more Magyar language learning and put in place a Magyar language exam for teachers. There were also encouraging signs from Berlin. In general, German public opinion had not stirred greatly and had followed the national interest and considerations of diplomacy. ${ }^{113}$ Bismarck,

\footnotetext{
${ }^{110}$ B. Jelavich, 'Foreign Policy and the National Question in the Habsburg Empire: A Memorandum of Kálnoky', Austrian History Yearbook 6-7 (1970-71), p. 152 and F. R. Bridge, From Sadowa to Sarajevo. The Foreign Policy of Austria-Hungary 1866-1914 (1972), pp. 123-4 and 137-40.

${ }^{111}$ In a letter written to Georg Daniel Teutsch, Rudolf Heinze downplayed the brochure's influence, though he admitted that its official status - it was being distributed by the Austro-Hungarian ambassador in Berlin - was of concern. Weisenfeld, Die Geschichte der politischen Publizistik, p. 106.

112 [R. Heinze], Deutsche Wahrheiten und Magyarische Einstellungen (Leipzig, 1882).

${ }^{113}$ See J. Kořalka, 'Deutschland und die Habsburgermonarchie 1848-1918' in A. Wandruszka and P. Urbanitsch, eds., Die Habsburgermonarchie 1848-1918. Vol. 6: Die Habsburgermonarchie im System der internationalen Beziehungen (2 Vols. Vienna, 1993), 2, pp. 1-158 and P. Burian, 'Deutschland und das
}

[Type text] 
remained publicly silent throughout the whole affair. The debate concerning the

Transylvanian Saxons and German-Hungarian relations now moved on to the imminent Mittelschule law.

The Mittelschule Law (1883) forms a coda to the Schulverein events. No real German support from the government or from the German general public for the Saxon cause had transpired and the Saxons remained subject to a dominant Hungarian state. Some Imperial German Reichstag representatives met on 15 February 1883, with the renowned legal professor Rudolf Gneist at their head, to protest against the Mittelschule law. Wattenbach gave a speech and a five-man committee drafted a strongly worded resolution against the law, also highlighting the centuries-old link between the Transylvanian Saxons and the German motherland. ${ }^{114}$ Yet the German public did not pick up the issue, neither during the ADS campaign nor during the passage of the Hungarian Mittelschule law and without governmental support the momentum behind the ADS and its supporters could not be maintained. ${ }^{115}$

Governmental circles in Berlin continued to be informed of matters in Hungary so, for example, Wattenbach prepared a memo for the Kaiser on the Mittelschule law. ${ }^{116}$ Bismarck received a confidential report dated 5 March 1883 on the ADS which described

Nationalitätenproblem der Habsburgermonarchie. Aus deutscher Sicht' in R. Kann and F. Prinz, eds., Deutschland und Österreich. Ein bilaterales Geschichtsbuch (Munich and Vienna, 1980), pp. 398-411. ${ }^{114}$ See Weisenfeld, Die Geschichte der politischen Publizistik, p. 190.

115 Of course, there were a number of organizations within Germany which remained interested in the German-speaking communities in the Habsburg Monarchy, but their support never spread to the general public and their influence on official policy towards Austria-Hungary was minimal. For example, on the Alldeutscher Verband and the Austria-Hungary see G. Tokody, 'Die Pläne des Alldeutschen Verbandes zur Umgestaltung Österreich-Ungarns', Acta Historica Academiae 9 (1963), pp. 39-67. In general, the bürgerliche middle classes, Catholic circles and the Social Democrats wanted the continued existence of Austria-Hungary and did not want to interfere greatly in its internal affairs. For many, Austria-Hungary's status as a valued ally was paramount. See Mommsen, Österreich-Ungarn aus der Sicht des deutschen Kaisereichs, pp. 213-6

${ }^{116}$ K. Vormeng, Geschichte des Allgemeinen Deutschen Schulvereins zur Erhaltung des Deutschtums im Auslande (Berlin, 1900), p. 23.

[Type text] 
its members as moderate people and emphasised the 'natural' alliance between the Germans and the Magyars against the Slavs. ${ }^{117}$ This position was backed up by the German consul in Budapest Wilhelm von Thielau, who after a meeting with the Hungarian Education Minister Trefort, wrote to Bismarck stating that German and Magyar interests were intertwined and that a strong Austria-Hungary was needed. In his reply to Thielau, Bismarck's views on the ADS, the Transylvanian Saxon position and the Hungarian-German relationship were made explicit.

The Hungarian government should not lay too much political meaning on the remonstrations of the Schulverein nor exaggerate their weight ..... we certainly look with concern at the position in which the German element in Hungary is under pressure, but we cannot take responsibility for it, similar to the Russian Eastern provinces .... In Hungary, because we place a high political worth in the strength and unity of the Hungarian Empire that our natural desires [to help German speakers] must take a back seat .... Magyars and Germans in Hungary are mutually dependent, [but] neither of the two nationalities [is dependent] on the Slavs. ${ }^{118}$

Bismarck described the ADS members as "opposition parliamentarians, doctrinaire professors and moderate people", all of whom had no political significance. ${ }^{119}$ Thus despite the protest from German parliamentarians plus further action from the ADS and a number of demonstrations in Transylvania, the Mittelschule law entered into effect in 1883.

The Schulverein incident along with the Mittelschule Law prompted a general change in Saxon political tactics, though there continued to be disagreements within the

\footnotetext{
${ }^{117}$ Gottas, Zur Nationalitätenpolitik in Ungarn, p. 98 and Gottas, Ungarn im Zeitalter des Hochliberalismus, p. 196.

${ }^{118}$ Quoted in Barta and Bell, Geschichte der Schutzarbeit, p.135.

${ }^{119}$ Quoted in Kořalka, Deutschland und die Habsburgermonarchie 1848-1918, p. 82.

[Type text]
} 
community. The furore sharpened viewpoints, forced people in public life to make a choice and highlighted the different political options of the Saxons. In particular, it had demonstrated the extent to which the German government would provide support for the Saxons. ${ }^{120}$ Twenty years later the German Chancellor Bernhard von Bülow, a former diplomat including stints in St. Petersburg and Bucharest, echoed Bismarck's words:

For our citizens of the Reich - there we must and will defend when and where any injustice towards them has occurred ... But for our national cousins (Volksgenossen), who are separated from us by international boundaries, we cannot intervene. That was an old principle of German policy, which had been put in place by Prince Bismarck, and from which no successor can depart. ${ }^{121}$

In 1882, when Bismarck had made the government's position clear, the pressure from German professors and parliamentarians gradually petered out. A resigned, pessimistic tone marked subsequent Imperial German publications about the Transylvanian Saxons. ${ }^{122}$

Amongst some prominent Transylvanian Saxons leaders, the Schulverein events and the Mittelschule Law forced a reassessment of their political tactics. From September

\footnotetext{
${ }^{120}$ An interesting parallel case occurred within the Romanian community of Transylvania. They had received a number of school subventions in the early 1890s from the Romanian government in Bucharest until, in the interests of foreign policy friendship with Austria-Hungary, the new Romanian Prime Minister Dimitrie Sturdza cancelled them in October, 1895. For a number of years leading up to 1895, the Hungarian government had put a lot of pressure on the Romanian government to provide detailed information on the subventions and to halt this interference in the internal affairs of another sovereign state. Ultimately, Sturdza, like Bismarck, was willing to sacrifice 'fellow nationals' overseas in the interests of a pragmatic foreign policy. K. Hitchins, A Nation Affirmed: The Romanian National Movement in Transylvania, 1860-1914 (Bucharest, 1999), pp. 307-29.

${ }^{121}$ From a speech in the Reichstag 19 March 1903. Quoted in Kořalka, 'Deutschland und die Habsburgermonarchie 1848-1918', p. 124. In 1897 when there were Transylvanian Saxon protests against Hungarian legislation on place names, the German government provided no support at all. B. Suttner, 'Die innere Lage Ungarns vor dem Ersten Weltkrieg in der Beurteilung deutscher Diplomaten', Südostdeutsches Archiv 13 (1970), p. 125.

${ }^{122}$ For example, R. Bergner, Die Frage der Siebenbürger Sachsen (Weimar, 1890). The Saxon two children system in particular is mentioned as disadvantageous. (p. 38). See also F. Guntram Schultheiss, Deutschtum und Magyarisierung in Ungarn und Siebenbürgen (Munich, 1898), which came out under the aegis of the Alldeutscher Verband, and portrayed the Magyars as all powerful. See also the scathing view of Wilhelm Jager in 1897, a German diplomat in Budapest, who wrote in official dispatches that the Transylvanian Saxons were now a 'degenerated race' and 'no longer Germans'. Quoted in Suttner, Die innere Lage Ungarns, p. 125.
}

[Type text] 
1883 a dialogue was begun between the Saxons - represented by the Lutheran Bishop and historian Georg Daniel Teutsch and the conciliatory leader Oscar von Meltzl - and the Hungarian government about fairer administrative appointments and a possible negotiated understanding. ${ }^{123}$ In 1885 Karl Wolff .- after fighting the 1876 Law, the 1879 and 1883 School Law, facing treason charges (1878) and actively participating in the 1882 Schulverein debate - suddenly resigned from the prominent public post of editor at the Siebenbürgisch-Deutsches Tagesblatt to become the director of the Hermannstädter Allgemeine Sparkassa. In his farewell article Wolff cited personal reasons and a lack of energy as the primary reasons for his resignation. ${ }^{124}$ Yet his bitterness at government policies and the inability of the Saxons to influence decision making were also clearly evident:

The State is a homestead of many peoples [Völker]; its existence depends on their mutual respect, support and encouragement ... [But] the guarantees of freedom for the general citizens were sacrificed at the altar of an unfortunate nationalities policy adopted by the state's decision makers.... ${ }^{125}$

Two years later, he would lay down his parliamentary mandate. The rest of his long life would be devoted to working tirelessly on improving the cultural and economic foundations of the Saxon community.

After the fall of Tisza in March 1890 Wolff was one of the instigators of the 1890 Hermannstadt Programme, the first full meeting of Saxon representatives since 1872 and a concerted attempt by Wolff and the 'Blacks' to unite Saxon representatives and arrive

\footnotetext{
${ }^{123}$ Göllner, Die Siebenbürger Sachsen, pp. 184-8. See also Egry, Ein anderer Ausgleich, pp. 51-2.

${ }^{124}$ Wolff, Schriften und Reden, pp. 133 and 136. The younger politician and journalist Rudolf Schuller, who would later also edit the SDT, described Wolff's attitude of non-engagement with Hungarian power politics as a 'form of bitter resignation'. R. Schuller, Politische Erinnerungen (Hermannstadt, 1940), p. 14. For his work at the Sparkassa see the Festschrift Dr. Carl Wolff als Direktor der Hermannstädter allgemeinen Sparkassa 1885 bis 1910. Festschrift aus Anlaß der 25. Jahreswende seiner Erwählung (Hermannstadt, 1910).

${ }^{125}$ Wolff, Schriften und Reden, pp. 135-6.

[Type text]
} 
at an understanding with the Hungarian governing elite. He was a member of the central committee which prepared the draft programme and was given the task of presenting it to the full meeting. In his speech Wolff spoke of the difficult fight against the recent laws and stressed the need for an integrated programme, not just addressing parliamentary affairs (as the 1881 electoral programme did) but encompassing the more important areas of economic, agricultural, communal and cultural work. ${ }^{126}$ These areas and the organisations which promoted them were, he argued, the true fundaments of a Volk's strength. The general goals of increased municipal autonomy, appreciation of the German language, respect for the law, Church and school and a possible change to the dualist system remained, however the focus should, Wolff argued, now be on organisational life. Wolff called for a Saxon conference every five years and a permanent Central Committee for initiatives and reform - in short, the beginnings of a modern political party. The programme was adopted without amendment and Wolff became the first President of the Central Committee. ${ }^{127}$

The initial signs were quite good. The Budapest government changed some key personnel - two Hungarian Lord Lieutenants in Transylvania, Dezső Bánffy and Gabor Bethlen, were replaced - in exchange for Saxon promises not to combine with other German speakers within Hungary. ${ }^{128}$ Moreover, in 1891 the Saxon politician Guido von

\footnotetext{
${ }^{126}$ Ibid, 143. F. Gottas, 'Vereine, Parteien und Interssenverbände der ungarländischen Deutschen' in Helmut Rumpler and Peter Urbanitsch, eds., Die Habsburgermonarchie 1848-1918. Vol. 8: Politische Öffentlichkeit und Zivilgesellschaft. Part 1: Vereine, Parteien und Interresenverbände als Träger der politische Partizipation (Vienna, 2006), pp. 1205-41 presents an overview of a surprisingly underresearched area.

${ }^{127}$ A copy of the 1890 Programme can be found at E. Wagner, ed., Quellen zur Geschichte der Siebenbürger Sachsen (Cologne-Vienna, 1981), pp. 242-5.

${ }^{128}$ Kroner, 'Introduction' in Wolff, Schriften und Reden, p. 20.

[Type text]
} 
Baußnern became Lord Lieutenant of Fogaras county. ${ }^{129}$ Despite these positive signs for the Saxons, the political climate changed almost immediately and the former LordLieutenant of Bistritz, Dezső Bánffy, became Hungarian Prime Minister in 1894, signalling a new intense phase of Magyarization. After the short lived unity, the Saxons were again divided; the Hermannstadt establishment (the 'Blacks') remaining true to the conciliatory 1890 Programme while the more radical Kronstadt grouping (the 'Greens') pushed for stronger opposition and possible political alliances with the Romanians and/or Banat Germans. ${ }^{130}$ Yet there were subtle differences compared to the old division between 'Old Saxons' and 'Young Saxons' of twenty years earlier. The 'Blacks' pushed for co-operation with the government primarily because there was no other alternative the events around the Schulverein and Mittelschule law had shown this. In their opinion, opposition would just make matters worse. This betrayed a defeatist attitude, quite different from the optimistic belief in liberal co-operation among the 'Young Saxons' of the mid-1860s. The 'Greens', unlike the oppositional 'Old Saxons', did not rely on arguments for the old legal privileges of self-autonomy nor appeals to the Emperor. Their programme counselled active opposition based on ethnic rights and national struggle. What brought about this change in political discourse? The main driver was the process of Hungarian state-building and its justification of modernisation, which, as Friedrich Teutsch observed years after these events, was especially dangerous for the Saxons. ${ }^{131}$ These general European-wide trends of democratisation, industrialisation, mobility, individualism, standardisation and state-building all threatened the Saxons'

\footnotetext{
${ }^{129}$ Baußnern had been against the interference of the ADS in Hungarian and Saxon affairs. Baußnern, Deutschland und Österreich-Ungarn, 193-6. Fogarasch/Făgăraş/Fogaras.

${ }^{130}$ Göllner, Die Siebenbürger Sachsen, pp. 190-205 and Kroner, Introduction, pp. 21-2.

[Type text]
} 
traditional privileged position in Transylvanian political life and their self-administered, relatively enclosed communities. ${ }^{132}$ In short, the transition from Stadtbürger to Staatsbürger was particularly problematic for the Transylvanian Saxons. The idea of state sovereignty, for example, was used by the Hungarian government to dismantle the Saxon privileges. Moreover, individual rights and equality before the law would not automatically benefit the Saxons, since laws were passed by a Magyar dominated parliament and enforcement was heavily reliant on the state bureaucracy (dominated by Magyars). This general modernisation process was a European-wide phenomenon, often associated with a nationalising drive but not always - Switzerland being an obvious example of decentralised, multi-lingual, culturally diverse development. This was not the case in Hungary. The Hungarian state, the main motor for the modernisation process, was firmly in the hands of the Magyar political elite and the Saxons looked to alternatives the Church, private schools (mostly associated with the Church), organisational life, agricultural co-operatives, Saxon credit institutions and the like - for protecting their way of life.

The Saxons were not the only grouping to rely on organisational life. Thomas Masaryk's Realist programme advocated 'quiet cultural work' and the moral transformation of the Czech people, while the Polish 'organic work' movement professed similar aims. Even the Austro-German liberals, who perceived themselves as the successors to the tradition of Josephinist state reform, had by the 1880s and 1890s turned to organisational life. For instance, Ernst von Plener, the principal opponent to Taaffe's

\footnotetext{
${ }^{131}$ See W. König, 'Thesen zur “Bildungsrevolution” bei den Siebenbürger Sachsen' in W. König, ed., Beiträge zur siebenbürgischen Schulgeschichte (Cologne-Weimar-Vienna, 1996), p. 281.
}

[Type text] 
Iron Ring government and the acknowledged leader of the Austro-German liberals, described the DSV as a substitute for twelve years away from the levers of state power. ${ }^{133}$ The Austro-German defence in Cisleithania had a different character to the Saxon situation since the Austro-Germans had laid claim to the traditions of the Austrian Gesamtstaat and felt aggrieved at their loss of position after the 1879 elections. The Saxons, on the other hand, accepted their minority status and never seriously challenged the Magyars' leading role within Hungarian state and society. For the Saxons, the main focus was on autonomy and rights within the framework of a Magyar-dominated Hungary. The main internal political disagreements were over the nature and extent of autonomy and rights.

Within Hungary other minority groups turned away from the state and developed their own organisational networks. For example, the Slovaks had little or no political representation in parliament and few possibilities of real influence at a local level. The vast majority of Slovaks were devout members of the Catholic Church whose institutions were also dominated by the Magyar elite. ${ }^{134}$ Like the Saxons, in the initial years of the dualist system, there was a division between Slovaks who were willing to work with the Hungarian government and those who advocated non-participation. Slovak resistance to Magyarization was concentrated around the cultural organisation Matica Slovenska which had a short but significant life from 1863 until 1875 whereupon the Budapest government closed it down for alleged Pan-Slav, anti-Magyar tendencies. The

\footnotetext{
132 This process received its classic formulation in E. Weber, Peasants into Frenchman. The Modernization of Rural France 1870-1914 (1977). Nothing on that scale for Central and Eastern Europe has ever been attempted.

${ }^{133}$ See M. Streitmann, 'Der Deutsche Schulverein vor dem Hintergrund der österreichischen Innenpolitik 1880-1918' (Univ. of Vienna, Ph.D. Dissertation, 1984), p. 148.

${ }^{134}$ There was also a small but active Slovak Lutheran minority.

[Type text]
} 
Romanians in Transylvania were in a stronger position and could use religious autonomy (in their case, the Orthodox and Uniate Churches) to build a political movement linked to cultural, educational and economic organisations. ${ }^{135}$ Romanian tactics relied on noninvolvement in the political process and direct appeals to the Emperor/King, though there was also a strong grouping arguing for active participation in the Hungarian parliament. ${ }^{136}$

In comparison to other minority groups in Hungary, the Transylvanian Saxons had more economic resources, stronger traditions and institutions of local autonomy, a better developed independent education system, a respected language, potential support from the powerful German-speaking world and, proportionately, favourable political representation in parliament. For these reasons and the general respect for German culture, the Magyar elite did not expect the Saxons to assimilate as easily as other minorities. Coupled with Saxon recognition of a Magyar-dominated Hungary, this mutual regard meant there was a real possibility of common work in creating a progressive, prosperous, modern state - provided Saxon demands for rights and autonomy were respected. There was no possible Saxon irredentism (since German-speaking Austria and Imperial Germany were geographically very distant) and there were precedents of Magyars and Saxons co-operating - in the old Transylvanian Diet and even examples during the 1848-49 Revolutions. Indeed, the 'Young Saxons', in the early days of dualism, were willing to join a combined effort with liberal Magyar elites and there were nearly always at least a few Saxon parliamentarians prepared to support the government,

\footnotetext{
${ }^{135}$ See the discussion in Hitchins, A Nation Affirmed, pp. 169-262. See also id., Orthodoxy and Nationality. Andreiu Şaguna and the Rumanians of Transylvania, 1846-1873 (Cambridge, Mass., 1977), id., Rumania 1866-1947 (Oxford, 1994), pp. 202-22 and Tanya Dunlop, 'Astra and the Appeal of the Nation: Power and Autonomy in Late-Nineteenth-Century Transylvania', Austrian History Yearbook 34 (2003), pp. 215-46.

[Type text]
} 
no matter how harsh the law (for example, Friedrich Wächter and Carl Fabritius had voted for the 1876 Law while Meltzl and Jakob Rannicher had supported it). As late as 1897 there were still four Saxon parliamentarians in the government party, including Guido von Baußnern. Many Saxons, through business and public affairs as well as personal contacts, were intimately involved with Hungarian institutions and authorities. Moreover, while there was little assimilation into the Hungarian community from the Saxon population, there was a marked increase in bilingualism.

The Schulverein events form a minor byway in the history of German and Hungarian diplomacy yet in the development of Transylvanian Saxon politics it represented a significant turning point. The tumult of 1882-83 made clear the position of the Transylvanian Saxons as a minority within a Magyar dominated state, without meaningful support from either Vienna or Berlin, increasingly adrift in an isolated pocket of South-Eastern Europe. The possible involvement of Vienna and Berlin for the Saxon cause had foundered on the realities of political expediency and the principles of modern state sovereignty. Democratic thinking and demographics in general - unlike for the Romanian movement - were of little political value, indeed posed a threat to the Saxon position. The Saxon response to these processes and to the Magyar-dominated state was not simply an increased German national consciousness, it was varied and changed over time. Many Saxons (like Karl Wolff) turned inward, tried to preserve their traditional way of life, while co-existing with the dominant Hungarian state, and watched as events unfolded in Budapest, Vienna and Berlin. Others, such as Guido von Baußnern, accepted dualism with its assumption of Magyar dominance (though there were many different reasons and degrees of willingness) and gradually became integrated into official

\footnotetext{
${ }^{136}$ Ibid, pp. 111-66. [Type text]
} 
institutions and Magyar speaking circles while continuing to assert their Saxon identity. A number of high profile activists, most prominently Edmund Steinacker who attempted to draw together German speakers throughout Hungary and would later use his links with Archduke Franz Ferdinand, continued to advocate increased ethnic awareness and political action. Others changed their viewpoint significantly in the course of years, such as Karl Lurtz, the leader of the oppositional, nationalist 'Greens' who upon becoming a parliamentary representative in Budapest in 1900 joined the Hungarian government party, accepted official posts in Kronstadt and began socialising with the local Magyar elite. ${ }^{137}$ These varied and changing responses reflected contrasting and individualised experiences to the Transylvanian Saxon dilemma and were evident in the fragmented, divisive, passionate nature of Saxon politics. Increased German nationalism was only one component of the Saxon jigsaw in the late nineteenth century.

\footnotetext{
${ }^{137}$ See the description of Lurtz in K. Schnell, Aus meinem Leben. Erinnerungen aus alter und neuer Zeit (Kronstadt, 1934), pp. 67-9 and a brief reference in R. Schuller, Politische Erinnerungen (Hermannstadt, 1940), p. 17.
}

[Type text] 